\title{
PENGARUH DISIPLIN DAN PARTISIPASI SISWA TERHADAP PRESTASI BELAJAR MELAKSANAKAN KOMUNIKASI BISNIS SISWA SMK DI KECAMATAN DAWARBLANDONG DENGAN PERCAYA DIRI SEBAGAI VARIABEL MODERASI
}

\author{
Septyan Budy Cahya, Pascasarjana Unesa \\ septyanbudycahya@gmail.com
}

\begin{abstract}
ABSTRAK
Penelitian ini bertujuan untuk menganalisis pengaruh disiplin belajar dan partisipasi terhadap prestasi belajar siswa dengan percaya diri sebagai moderasi. Populasi dalam penelitian adalah siswa kelas X tahun ajaran 2013-2014 dengan total 117 siswa. Sampel diambil dengan mengunakan teknik simple random sampling berjumlah 88 siswa. Penelitian menggunakan metode Survei Eksplanasi dengan menggunakan pendekatan kuantitatif yang terdiri dari variabel disiplin belajar, partisipasi, percaya diri, dan prestasi belajar. Hasil penelitian menunjukkan disiplin belajar dan partisipasi memiliki pengaruh sigifikan dan positif terhadap prestasi belajar siswa baik secara parsial dan simultan. Percaya diri tidak berpengaruh signifikan sebagai moderasi pengaruh disiplin belajar terhadap prestasi belajar. Percaya diri berpengaruh signifikan sebagai moderasi pengaruh partisipasi siswa terhadap prestasi belajar. Secara simultan terdapat pengaruh positif dan signifikan terhadap pengaruh disiplin belajar dan partisipasi terhadap prestasi belajar siswa kelas X SMK di Kecamatan Dawarblandong.
\end{abstract}

Kata kunci: Disiplin belajar, partisipasi, percaya diri, prestasi belajar

\begin{abstract}
This study aimed to analyze the influence of the discipline of learning and participation on student achievement with confidence as moderation. The population is class $X$ in academic year 2013-2014 with a total of 117 students. 88 students Samples were taken by using simple random sampling technique. Research using method of explanation by quantitative approach that consists of learning the discipline, participation, confidence, and learning achievement. The results showed the discipline of learning and participation has a positive influence and significant on student achievement both partially and simultaneously. Confidence no significant effect as a moderating influence on the learning achievement of learning discipline. Confidence has significant effect as a moderation influencing student participation on learning achievement. Simultaneously there is a positive and significant impact on the discipline of learning and participation influences on student achievement in class X SMK the district of Dawarblandong.
\end{abstract}

Keywords: Discipline learning, participation, self-confidence, learning achievement 


\section{PENDAHULUAN}

Dalam dunia pendidikan, prestasi belajar merupakan suatu hal yang sangat penting dan sering dijadikan pokok pembicaraan dan permasalahan antar guru. Hal ini memang cukup beralasan karena prestasi belajar yang dicapai siswa tidak dilepaskan dengan masalah evaluasi pendidikan. Dengan demikian prestasi belajar dapat mencerminkan kemampuan siswa dalam mempelajari suatu mata pelajaran. Memperoleh prestasi belajar yang baik bukanlah hal yang mudah, banyak faktor yang mempengaruhi, faktor-faktor tersebut antara lain guru, orang tua dan siswa. Faktor siswa memegang peranan penting dalam pencapaian prestasi belajar, karena siswa yang melakukan kegiatan belajar perlu memiliki ketekunan belajar, motivasi berprestasi yang tinggi, disiplin belajar yang baik, dan berpartisipasi dalam pelaksanaan pembelajaran (Suryabrata, 2005).

Sekolah adalah lembaga formal sebagai wadah kegiatan belajar mengajar. Agar proses belajar mengajar lancar, maka seluruh siswa harus mematuhi tata tertib dengan penuh rasa disiplin yang tinggi. Menurut Soegeng Pridjodarminto dalam Tu'u (2004) disiplin adalah suatu kondisi yang tercipta dan terbentuk dari serangkaian perilaku yang menunjukkan nilai-nilai ketaatan, kepatuhan, kesetiaan, atau keterikatan terhadap sesuatu peraturan tata tertib. Disiplin dapat menunjukkan mana yang boleh dan mana yang tidak boleh dilakukan. Perilaku disiplin sangat dibutuhkan dalam pembinaan dan juga perkembangan siswa untuk menuju masa depan yang lebih baik. Perlunya disiplin di sekolah adalah mendidik siswa untuk berperilaku sesuai dengan standar yang ditetapkan (Mulyasa, 2003). Masalah disiplin siswa di sekolah tidak dapat dipisahkan dari tata tertib sekolah. Jadi disiplin siswa merupakan cerminan langsung dari kepatuhan seorang siswa dalam melaksanakan peraturan-peraturan yang berlaku di sekolahnya. Kepatuhan siswa dalam melaksanakan tata tertib sekolah akan mendukung terciptanya kegiatan belajar mengajar yang efektif dan berguna untuk membantu dalam mencapai hasil belajar yang optimal.

Kedisiplinan belajar siswa dipengaruhi beberapa faktor baik dari dalam maupun dari luar individu, pengaruh dari dalam individu misalnya: sifat bermalasmalas, keengganan memusatkan pelajaran, kebiasaan melamun dan lain sebagainya. Sedangkan pengaruh dari luar individu misalnya: suasana di rumah, suasana di sekolah, waktu yang tersedia, dan lain sebagainya. Untuk mewujudkan kedisiplinan belajar perlu diadakan pembinaan pribadi siswa di sekolah (Hurlock, 2000). Siswa yang memiliki disiplin belajar akan menunjukkan kesiapannya dalam mengikuti pelajaran kelas, mengerjakan tugas-tugas pekerjaan rumah dan memiliki kelengkapan belajar misalnya buku dan alat belajar lainnya. Sebaliknya siswa yang kurang disiplin belajar maka tidak menunjukkan kesiapan dalam mengikuti pelajaran, tidak mengerjakan tugas-tugas, suka membolos, tidak mengerjakan PR, dan tidak memiliki kelengkapan belajar (Tu'u, 2004).

Siswa merupakan inti dalam proses kegiatan belajar mengajar, dan guru melakukan kegiatan pembelajaran yang dapat menjadikan siswa untuk aktif, sehingga siswa tersebut mampu mengubah tingkah lakunya menjadi lebih baik dan siswa dapat berperan dan berpartisipasi aktif dalam melakukan kegiatan belajar. Partisipasi siswa dalam belajar tidak bersifat dikhotomis, artinya ada atau tidak ada partisipasi, melainkan bersifat kontinum, artinya partisipasinya terentang dari yang paling rendah sampai yang paling tinggi (Darsono, 2002). Guru yang 
berinteraksi dengan siswa secara akrab, dapat menyebabkan proses belajar mengajar itu akan lebih baik dan lancar. Selain itu siswa dapat merasa dekat dengan guru, sehingga mampu mendorong siswa untuk berpartisipasi secara aktif dalam belajar. Peran partisipasi siswa dalam pelaksanaan proses belajar mengajar adalah sangat penting, karena dari sinilah guru dapat memberikan perhatian yang berbeda kepada siswa yang kurang berpartisipasi. Partisipasi siswa dalam belajar dapat ditunjukkan dengan keaktifannya dalam proses belajar mengajar, memperhatikan guru saat menerangkan di kelas, dan menanyakan apa yang menjadi pertanyaan dalam pikirannya, serta dapat berkomunikasi timbal balik dalam pembelajaran.

Selain disiplin dan partisipasi siswa, hal lain yang perlu diperhatikan adalah percaya diri. Menurut Goleman (2003), kepercayaan diri adalah kesadaran yang kuat tentang harga dan kemampuan diri sendiri. Seseorang yang percaya diri akan berani tampil dengan keyakinan diri, berani menyatakan keberadaannya, berani menyuarakan pandangan yang tidak popular dan bersedia berkorban demi kebenaran serta tegas, mampu membuat keputusan yang baik kendati dalam keadaan tidak pasti dan tertekan.

Wiyalah Kecamatan Dawarblandong Kabupaten Mojokerto terdapat dua Sekolah Menegah Kejuruan (SMK), yaitu SMK Nasional Dawarblandong dan SMK Perbankan. Kedua sekolah tersebut merupakan salah satu dari sekian banyak sekolah menengah kejuruan yang berusaha mencetak lulusan yang siap kerja dan siap bersaing dalam dunia kerja. Dalam menghadapi tantangan, seluruh pihak sekolah berusaha untuk memenuhi segala kebutuhan guna menunjang proses belajar yang baik dan terencana. Salah satu usaha mewujudkan hal tersebut yaitu dengan cara menjalin kerjasama dengan banyak instansi dan perusahaan, sebagai fasilitas untuk siswa dalam melaksanakan kegiatan praktek kerja dan penempatan kerja setelah lulus sekolah. Hal ini tentunya akan menjadi tanggung jawab untuk sekolah dalam mencetak lulusan yang berkompetensi dan siap kerja serta menjadi motivasi siswa untuk belajar dengan baik.

Melaksanakan komunikasi bisnis merupakan salah satu mata pelajaran yang perlu atau penting untuk diberikan dan dikuasai oleh siswa. Materi ini berfungsi membekali peserta didik agar memiliki kompetensi kerja yang baik khususnya cara dan etika berkomunikasi, serta bekerjasama dengan kolega dan pelanggan di dunia kerja. Sehingga pengetahuan yang diperoleh nantinya dapat diterapkan dalam kehidupan sehari-hari pada lingkungan keluarga, masyarakat maupun di tempat kerja. Berdasarkan observasi awal yang dilakukan oleh peneliti diketahui bahwa prestasi belajar mata pelajaran melaksanakan komunikasi bisnis kelas $\mathrm{X}$ belum seluruhnya mencapai hasil yang maksimal. Masih terdapat siswa yang mengalami kesulitan dalam memenuhi Kriteria Ketuntasan Minimal (KKM), dan $40 \%$ rata-rata siswa menempuh ujian remedial untuk memperbaiki nilainya. Sebagian besar siswa kurang cakap dan masih takut dalam bertanya ataupun berpendapat didalam kelas ataupun didepan orang banyak. Rata-rata hanya 50\% siswa yang aktif dan berpartisipasi dalam proses belajar mengajar di kelas.

Kebanyakan siswa masih belum dapat mengelola dan menyampaikan hasil tugas atau pekerjaannya secara komunikatif. Mengidentifikasi mata pelajaran komunikasi bisnis memiliki materi yang cukup banyak dan membutuhkan interaksi dan komunikasi. Maka, partisipasi siswa sangat dibutuhkan untuk mepermudah pembelajaran dan sekaligus sebagai proses pembiasaan dalam 
praktek di dunia kerja. Selain itu guru juga dapat menilai siswa dari partisipasinya didalam proses belajar mengajar. Sakdiyah (2007) dalam penelitiannya menjelaskan adanya hubungan positif antara partisipasi dan prestasi belajar. Siswa yang memiliki partisipasi aktif dalam pembelajaran akan memperikan dampak positif dalam peningkatan prestasi belajarnya. Cheek (2005) juga menjelaskan dalam penelitiannya bahwa partisipasi secara positif berhubungan dengan prestasi belajar.

Hal lain yang peneliti peroleh adalah masalah disiplin belajar siswa. Dengan tujuan manajemen sekolah untuk membangun dan menjadikan sekolah menjadi tempat pendidikan yang baik dan menciptakan anak didik yang kompeten, tentunya seluruh pihak sekolah berusaha keras untuk merintis dan merealisasikannya. Salah satu usaha yang dilakukan adalah dengan menerapkan kedisiplinan dan tata tertib di sekolah dengan baik. Namun dalam proses kearah tujuan tersebut tidak mudah. Masih ada siswa yang tidak disiplin dengan melanggar peraturan sekolah ataupun tidak menjalanklan tata-tertib yang ada, seperti terlambat masuk ke kelas, tidak membawa buku pelajaran, dan kurang perhatian terhadap kegiatan pembelajaran. Masalah kedisiplinan siswa yang paling sering terjadi adalah keterlambatan siswa datang di sekolah. Baik di SMK Nasional Dawarblandong maupun di SMK Perbankan juga mengalami hal yang sama. Dimana rata-rata 10\% siswa terlambat datang ke sekolah ataupun masuk ke dalam kelas. Hal ini akan mengurangi persiapan siswa dalam kegiatan belajar di kelas. Kondisi seperti ini tentunya akan mengurangi keberhasilan siswa dalam kegiatan belajar mengajar dikarenakan disiplin belajar merupakan suatu yang sangat penting dalam kegiatan belajar mengajar.

Kesadaran yang tinggi dalam disiplin akan menumbuhkan rasa tanggung jawab siswa terhadap arti pentingnya belajar. Tu'u (2004) menjelaskan siswa yang memiliki disiplin belajar akan menunjukkan kesiapannya dalam mengikuti pelajaran kelas, mengerjakan tugas-tugas pekerjaan rumah dan memiliki kelengkapan belajar misalnya buku dan alat belajar lainnya. Sebaliknya siswa yang kurang disiplin belajar maka tidak menunjukkan kesiapan dalam mengikuti pelajaran, tidak mengerjakan tugas-tugas, suka membolos, tidak mengerjakan PR, dan tidak memiliki kelengkapan belajar. Hal ini menunjukkan bahwa siswa yang memiliki disiplin belajar akan lebih siap dalam melaksanakan proses belajar mengajar disekolah. Saputro (2012) dalam penelitiannya menjelaskan bahwa disiplin belajar berpengaruh positif dan signifikan terhadap prestasi belajar. Pasternak (2013) juga menjelaskan dalam penelitiannya bahwa disiplin memberikan korelasi positif terhadap prestasi belajar.

Selain disiplin dan partisipasi siswa, faktor lain yang mempengaruhi prestasi belajar adalah percaya diri. Setiap individu siswa memiliki lingkungan dan latar belakang yang berbeda-beda, sehingga hal itu mempengaruhi kepribadian dan pembentukan rasa percaya diri dalam berinteraksi dengan lingkungannya. Dengan rasa percaya diri, siswa akan mudah berinteraksi didalam lingkungan belajarnya. Namun tidak semua individu memilki rasa percaya diri yang cukup. Perasaan minder, malu, sungkan dapat menjadi kendala seorang individu siswa dalam proses belajarnya disekolah maupun di lingkungannya, karena dengan rasa minder tersebut individu akan sering merasa tidak yakin dengan kemampuan dan ketrampilan yang dimilikinya, sehingga jadi lebih menutup diri, dan kurang mendapatkan banyak informasi langsung yang dibutuhkan. Berdasarkan data awal 
yang didapat peneliti dari konselir dan guru di SMK Nasional Dawarblandong dan SMK Perbankan, diketahui sebagian siswa masih memiliki kecenderungan untuk menutup diri dan enggan untuk mengungkapkan diri, terutama dalam proses belajar mengajar. Hal tersebut dikarenakan adanya sikap kurang percaya diri dalam diri siswa.

Dalam penelitian ini, peneliti memilih percaya diri sebagai variabel moderasi dalam pengaruh disiplin dan partisipasi siswa terhadap prestasi belajar. Menurut Nurmalina dan Syaifullah (2010) percaya diri merupakan sikap positif yang dimiliki seseorang individu yang membiasakan dan memupukkan dirinya untuk mengembangkan penilaian positif baik terhadap diri sendiri maupun terhadap orang lain, lingkungan serta situasi yang dihadapinya untuk meraih apa yang diinginkan. Siswa yang memiliki percaya diri akan bertanggung jawab dengan tugas-tugasnya, dan siswa yang memiliki tanggung jawab yang besar terhadap tugas dan kewajiban yang dimiliki maka siswa tersebut memiliki kedisiplinan yang baik dalam belajarnya. Sehingga tingginya percaya diri yang dimiliki oleh setiap siswa akan memberikan hal yang positif dengan semakin baiknya kedisiplinan belajar siswa tersebut. Senada dengan pendapat Lauster (2002) menjelaskan bahwa kepercayaan diri sebagai salah satu aspek kepribadian yang berupa keyakinan akan kemampuan diri seseorang sehingga tidak terpengaruh oleh orang lain dan dapat bertindak sesuai kehendak, gembira, optimis, cukup toleran dan bertanggung jawab. Ia menambahkan bahwa kepercayaan diri berhubungan dengan kemampuan melakukan sesuatu yang baik.

Siswa yang mempunyai percaya diri yang tinggi akan berusaha bertanggung jawab terhadap semua kegiatan atau pekerjaannya dan melakukan hak dan kewajibannya dengan baik. Menurut Goleman (2003), kepercayaan diri adalah kesadaran yang kuat tentang harga dan kemampuan diri sendiri atau kemampuan yang dapat memperkuat atau melemahkan seseorang dalam meningkatkan pemahaman, prestasi dan mencapai tujuan dan cita-citanya. Orang dengan kecakapan ini akan berani tampil dengan keyakinan diri, berani menyatakan keberadaannya, berani menyuarakan pandangan yang tidak popular dan bersedia berkorban demi kebenaran serta tegas, mampu membuat keputusan yang baik kendati dalam keadaan tidak pasti dan tertekan. Penelitian Rocca (2010), yang menyebutkan bahwa percaya diri siswa dapat memberikan pengaruh yang positif terhadap partisipasi yang kemudian akan meningkatkan prestasi belajar.

\section{METODE PENELITIAN}

Jenis penelitian yang akan dipakai peneliti yaitu jenis penelitian survey dengan menggunakan pendekatan kuantitatif. Penelitian ini menggunakan empat macam variabel yang terdiri dari tiga variabel independent dan satu variabel dependent. Yang menjadi variabel bebas dalam penelitian ini adalah disiplin belajar $\left(\mathrm{X}_{1}\right)$, partisipasi $\left(\mathrm{X}_{2}\right)$, dan percaya diri $\left(\mathrm{X}_{3}\right)$. Sedangkan yang menjadi variabel terikat dalam penelitian ini adalah prestasi belajar (Y). Jumlah keseluruhan populasi adalah 117 siswa yang menerima mata pelajaran produktif atau kejuruan melaksanakan komunikasi bisnis. Sampel yang digunakan sebanyak 88 siswa dan teknik pengambilan sampelnya adalah simple random sampling.

Teknik pengumpulan data dalam penelitian ini digunakan dengan berbagai cara dokumentasi dan angket. Dokumentasi untuk mengumpulkan data dari 
sebagian variabel prestasi belajar, sedangkan angket untuk mengumpulkan data dari variabel disiplin belajar, partisipasi, dan percaya diri. Teknik analisa data yang dgunakann adalah regresi ganda dengan menggunakan rumus $\mathbf{Y}=\mathbf{a}+\mathbf{b}_{\mathbf{1}} \mathbf{X}_{\mathbf{1}}$ $+\mathbf{b}_{2} \mathbf{X}_{2}$. Dalam penelitian ini menggunakan variabel moderasi, sehingga analisis regresi selanjutnya akan dilakukan secara bersama-sama, yaitu semua variabel independen dan variabel moderating. Dalam penelitian ini pengujian dilakukan dengan uji selisih mutlak, adapun rumus persamaan yang akan digunakan dalam pengujian ini adalah: $\mathbf{Y}=\mathbf{a}+\mathbf{b}_{1} \mathbf{X}_{\mathbf{1}}+\mathbf{b}_{2} \mathbf{X}_{2}+\mathbf{b}_{3} \mathbf{X}_{\mathbf{3}}+\mathbf{b}_{4}\left|\mathbf{X}_{\mathbf{1}}-\mathbf{X}_{\mathbf{3}}\right|+\mathbf{b}_{5} \mid \mathbf{X}_{2}-\mathbf{X}_{3}$. Ada dua uji statistik yang digunakan dalam penelitian ini yaitu uji $t$ dan uji $F$.

\section{HASIL DAN PEMBAHASAN}

Uji normalitas menggunakan cara uji Kolmogrov - Smirnov. Adapun tujuan melakukan uji normalitas adalah untuk menguji bahwa sampel telah mewakili populasi, sehingga hasil penelitian dapat digeneralisasikan pada populasi. Nilai Kolmogrov - Smirnov yang dihasilkan sebesar 0,674 dengan tingkat signifikansi sebesar 0,754. Tingkat signifikansi yang dihasilkan tersebut lebih dari 5\% yang berarti residual mengikuti distribusi normal. Sehingga data dalam penelitian ini dapat dikatakan berdistribusi normal.

Uji ini digunakan untuk mengetahui apakah model regresi pada penelitian ini ditemukan adanya korelasi diantara variabel bebasnya. Model regresi yang baik seharusnya tidak terjadi korelasi diantara variabel bebas atau non multicolinierity. Untuk mendeteksi ada tidaknya multikolinieritas adalah dengan melihat nilai Variance Inflation Factor (VIF). Dan hasil uji multikolinieritas nilai semua variabel bebas diatas 0,1 dan nilai VIF untuk semua variabel bebasnya berada di bawah 10. Maka dapat dikatakan bahwa variabel bebas yang digunakan dalam model adalah dapat dipercaya dan obyektif atau terhindar dari masalah multikolinieritas.

Heteroskedastisitas bertujuan menguji apakah dalam model regresi terjadi ketidaksamaan varians dari residual satu pengamatan ke pengamatan lain. Cara mengetahui heteroskedastisitas dalam regresi dapat dilakukan dengan menggunakan uji koefisiensi korelasi Rank Spearman. Hasil uji heteroskedastisitas menunjukkan bahwa nilai signifikan yang dihasilkan oleh semua variabel melebihi alpha $(\alpha)$ yang ditentukan yaitu 5\%. Semua nilai Sig. > 0,05 berarti tidak terdapat gejala heteroskedastisitas.

Berdasarkan uji regresi berganda diperoleh persamaan regresi sebagai berikut: $\mathrm{Y}=49,122+0,177 \mathrm{X}_{1}+0,642 \mathrm{X}_{2}$ dari persamaan ini menunjukkan bahwa disiplin belajar dan partisipasi memiliki hubungan yang searah dengan prestasi belajar. Untuk uji t Nilai t hitung pada variabel disiplin belajar $\left(\mathrm{X}_{1}\right)$ sebesar 3,310 dengan tingkat signifikansi kurang dari 5\% yaitu 0,001. Hal ini berarti bahwa disiplin belajar $\left(\mathrm{X}_{1}\right)$ secara parsial berpengaruh secara signifikan terhadap prestasi belajar $(\mathrm{Y})$. Besarnya pengaruh disiplin belajar $\left(\mathrm{X}_{1}\right)$ terhadap prestasi belajar $(\mathrm{Y})$ adalah $3,03 \%$. Nilai t hitung pada variabel partisipasi $\left(\mathrm{X}_{2}\right)$ sebesar 10,307 dengan tingkat signifikansi kurang dari 5\% yaitu 0,000. Hal ini berarti bahwa partisipasi $\left(\mathrm{X}_{2}\right)$ secara parsial berpengaruh secara signifikan terhadap prestasi belajar $(\mathrm{Y})$. Besarnya pengaruh partisipasi $\left(\mathrm{X}_{2}\right)$ terhadap prestasi belajar (Y) adalah 30,03\%. 
Uji $\mathrm{F}$ ini digunakan untuk mengetahui apakah variabel disiplin belajar $\left(\mathrm{X}_{1}\right)$ dan partisipasi $\left(\mathrm{X}_{2}\right)$ secara bersama-sama berpengaruh secara signifikan terhadap variabel prestasi belajar (Y). Nilai Fhitung yang dihasilkan adalah 134,540 dengan nilai signifikansi 0,000 kurang dari 0,05 . Sehingga dapat disimpulkan bahwa disiplin belajar dan partisipasi siswa secara simultan berpengaruh signifikan terhadap prestasi belajar. Berarti $\mathrm{H}_{0}$ ditolak dan hipotesis alternatif diterima.

Besarnya pengaruh disiplin belajar dan partisipasi secara simultan terhadap prestasi belajar siswa dapat dilihat dari koefisien determinasi ( $R$-square). Nilai RSquare yang dihasilkan sebesar 0,760 menunjukkan bahwa prestasi siswa dipengaruhi oleh disiplin belajar dan partisipasi siswa sebesar 76,0\% sedangkan $24,0 \%$ dipengaruhi oleh faktor-faktor lain yang tidak dijelaskan dalam penelitian ini.

Pengujian hipotesis selanjutnya akan dilakukan bersama-sama, yaitu semua variabel independent disiplin belajar $\left(\mathrm{X}_{1}\right)$ dan partisipasi $\left(\mathrm{X}_{2}\right)$ dan variabel moderating percaya diri $\left(\mathrm{X}_{3}\right)$. Dimana diperoleh hasil regresi sebagai berikut : $\mathrm{Y}=$ $81,730+0,974 \mathrm{ZX}_{1}+1,403 \mathrm{ZX}_{2}+2,523 \mathrm{ZX}_{3}-0,019$ moderating $1+1,428$ Moderating2. Nilai t hitung pada variabel disiplin belajar $\left(\mathrm{ZX}_{1}\right)$ sebesar 3,519 dengan tingkat signifikansi kurang dari $5 \%$ yaitu 0,001 . Hal ini berarti bahwa disiplin belajar $\left(\mathrm{ZX}_{1}\right)$ secara parsial berpengaruh secara signifikan terhadap prestasi belajar (Y). Nilai t hitung pada variabel partisipasi $\left(\mathrm{ZX}_{2}\right)$ sebesar 3,368 dengan tingkat signifikansi kurang dari $5 \%$ yaitu 0,001 . Hal ini berarti bahwa partisipasi $\left(Z_{2}\right)$ secara parsial berpengaruh secara signifikan terhadap prestasi belajar (Y). Nilai t hitung pada variabel percaya diri $\left(\mathrm{ZX}_{3}\right)$ sebesar 6,111 dengan tingkat signifikansi kurang dari 5\% yaitu 0,000. Hal ini berarti bahwa percaya diri $\left(\mathrm{ZX}_{3}\right)$ secara parsial berpengaruh secara signifikan terhadap prestasi belajar (Y). Nilai $\mathrm{t}$ hitung pada variabel moderating1 sebesar -0,044 dengan tingkat signifikansi lebih dari 5\% yaitu 0,965 . Hal ini berarti bahwa variabel moderating1 secara parsial tidak berpengaruh secara signifikan terhadap prestasi belajar (Y). Sehingga percaya diri bukan merupakan moderasi dalam pengaruh disiplin belajar terhadap prestasi. Nilai t hitung pada variabel moderating2 sebesar 2,251 dengan tingkat signifikansi kurang dari 5\% yaitu 0,027 . Hal ini berarti bahwa variabel moderating2 secara parsial berpengaruh secara signifikan terhadap prestasi belajar (Y).

Dari hasil uji ANOVA atau F Test, didapat $F$ hitung sebesar 97,512 dengan signifikansi 0,000. Karena propabilitas 0,000 jauh lebih kecil dari alpha 0,050, maka dapat dikatakan bahwa variabel $\mathrm{ZX}_{1}, \mathrm{ZX}_{2}, \mathrm{ZX}_{3}$, Moderating1, dan Moderating2 secara bersama-sama berpengaruh signifikan terhadap prestasi belajar komunikasi bisnis. Besarnya pengaruh disiplin belajar, partisipasi, dan percaya diri secara simultan terhadap prestasi belajar siswa dapat dilihat dari koefisien determinasi ( $R$-square). Nilai $R$-Square yang dihasilkan sebesar 0,856 menunjukkan bahwa prestasi siswa dipengaruhi oleh disiplin belajar, partisipasi, dan percaya diri sebagai moderasi sebesar $85,6 \%$ sedangkan $14,4 \%$ dipengaruhi oleh faktor-faktor lain yang tidak dijelaskan dalam penelitian ini.

Berdasarkan hasil penelitian menunjukkan bahwa disiplin belajar secara parsial berpengaruh signifikan terhadap prestasi belajar. Hasil tersebut menjelaskan bahwa semakin tinggi tingkat disiplin belajar siswa maka semakin tinggi prestasi belajar melaksanakan komunikasi bisnis siswa kelas X SMK di Kecamatan Dawarblandong. Dengan demikian menunjukkan bahwa disiplin 
belajar sangat diperlukan untuk mendukung tercapainya prestasi belajar yang optimal.

Hasil penelitian ini sesuai dengan pendapat Tu'u (2004) yang menyatakan bahwa pencapaian prestasi belajar yang baik selain karena adanya tingkat kecerdasan yang cukup, baik, dan sangat baik, juga didukung oleh adanya disiplin sekolah yang ketat dan konsisten, disiplin individu dalam belajar, dan juga karena perilaku yang baik. Hasil penelitian yang dilakukan Saputro (2012) dimana dalam hasil penelitiannya menyebutkan terdapat pengaruh positif dan signifikan disiplin belajar terhadap prestasi belajar. Selanjutnya penelitian yang dilakukan oleh Sakdiyah (2007) juga menjelaskan bahwa adanya pengaruh positif antara disiplin belajar dengan prestasi belajar.

Disiplin belajar siswa berpengaruh positif dan signifikan terhadap prestasi belajar didukung dengan temuan indikator-indikator pada variabel disiplin belajar yaitu patuh dan taat terhadap tata tertib di sekolah, persiapan belajar siswa, perhatian terhadap kegiatan pembelajaran, dan menyelesaikan tugas pada waktunya memiliki nilai rata-rata tinggi. Indikator patuh dan taat terhadap tata tertib di sekolah memiliki penilain paling tinggi. Dimana hal ini dikarenakan kedisiplinan yang di terapkan disekolah dilaksanakan dengan baik. Sangsi tegas yang diberikan oleh pihak sekolah untuk siswa yang melanggar tata tertib membuat siswa lebih disiplin, meski masih ada sebagian siswa yang masih sering melanggar tata tertib sekolah. Sedangkan indikator persiapan belajar memiliki nilai paling rendah. Hal ini menunjukkan persiapan belajar siswa perlu ditingkatkan. Dimana masih ada sebagian siswa yang kurang dalam mempersiapkan belajarnya, seperti kurang termotivasi untuk menerima pelajaran, belum siap untuk menerima pelajaran dari guru, dan kurangnya perhatian dalam mempersiapkan perlengkapan belajarnya. Masalah disiplin siswa di sekolah tidak dapat dipisahkan dengan masalah tata tertib sekolah. Disiplin siswa merupakan cerminan langsung dari kepatuhan seorang siswa dalam melakukan peraturanperaturan yang berlaku di lingkungan sekolah. Kepatuhan siswa dalam melaksanakan tata tertib sekolah akan mendukung terciptanya kegiatan belajar mengajar yang efektif dan berguna untuk mencapai hasil belajar yang optimal.

Dari hasil tersebut dapat dikatakan bahwa disiplin belajar yang tinggii, akan menghasilkan prestasi siswa yang baik pada pelajaran melaksanakan komunikasi bisnis, dan siswa yang memiliki disiplin belajar yang rendah, akan menghasilkan prestasi siswa yang rendah. Dari hasil analisis data, telah terbuki bahwa terdapat pengaruh yang signifikan antara disiplin belajar siswa dengan prestasi belajar melaksanakan komunikasi bisnis. Hal ini sesuai dengan teori dan penelitian yang telah dilakukan sebelumnya yang menyebutkan bahwa semakin tinggi disiplin belajar siswa akan meningkatkan prestasi belajar.

Berdasarkan hasil analisis menunjukkan bahwa percaya diri secara parsial berpengaruh signifikan terhadap prestasi belajar. Hal ini berarti menjelaskan bahwa semakin tinggi tingkat partisipasi siswa maka semakin tinggi prestasi belajar melaksanakan komunikasi bisnis siswa kelas X SMK di Kecamatan Dawarblandong. Dengan demikian menunjukkan bahwa disiplin belajar sangat diperlukan untuk mendukung tercapainya prestasi belajar yang optimal. Hasil penelitian ini sesuai dengan penelitian yang dilakukan oleh Sakdiyah (2007) dimana dalam hasil penelitiannya menyebutkan terdapat pengaruh positif dan signifikan partisipasi siswa terhadap prestasi belajar. 
Berdasarkan hasil angket yang diberikan kepada siswa, indikator-indikator pada variabel partisipasi yaitu siswa terlibat dalam proses belajar, berlatih untuk menjelajah mencari dan mempertanyakan sesuatu, menyelidiki jawaban atas pertanyaan, mengelola dan menyampaikan hasil perolehan secara kumulatif memiliki nilai rata-rata tinggi. Indikator menyelidiki jawaban atas pertanyaan memiliki penilain paling tinggi. Hal tersebut tidak lepas dari peran guru yang selalu memberikan stimulus agar siswa selalu aktif dan turut berpartisipasi dalam menyelidiki, mengelola, dan menjawab setiap pertanyaan yang diberikan oleh guru. Guru memberikan kesempatan kepada setiap siswa untuk selalu menyelidiki jawaban atas setiap pertanyaan yang ada. Sehingga siswa dapat mengelola sendiri pertanyaan dan informasi atau jawaban yang mereka pahami. Guru yang dapat berinteraksi dengan siswa secara baik, menjadikan proses belajar mengajar itu akan lebih baik dan lancar. Siswa juga dapat merasa dekat dengan guru, sehingga siswa akan berpartisipasi secara aktif dalam belajar. Partisipasi siswa dalam pelaksanaan pembelajaran adalah sangat penting, karena dari sinilah guru dapat memberikan perhatian yang berbeda kepada mereka yang kurang berpartisipasi.

Sedangkan dalam variabel partisipasi, indikator berlatih untuk menjelajah, mencari, dan mempertanyakan sesuatu memiliki nilai paling rendah. Hal ini dikarenakan kebanyakan siswa cenderung malas dan takut dalam mencari atau bertanya kepada guru jika ada yang tidak dimengerti. Kalau dibandingkan dengani indikator menyelidiki jawaban atas pertanyaan yang memiliki penilaian lebih tinggi, dapat kita ketahui bahwa siswa SMK di Kecamatan Dawarblandong lebih cenderung berpartisipasi aktif apabila ada media atau stimulus dari guru. Dimana siswa cenderung lebih suka berpartisipasi aktif dalam hal menjawab pertanyaan yang diajukan oleh guru dibandingkan dengan bertanya dan mencari informasi kepada guru. Dengan demikian guru diharapkan dapat berperan aktif dan mampu menjadi media untuk meningkatkan partisipasi siswa.

Dari hasil tersebut dapat dikatakan bahwa partisipasi yang tinggi, akan menghasilkan prestasi siswa yang baik pada pelajaran melaksanakan komunikasi bisnis, dan siswa yang memiliki partisipasi yang rendah, akan menghasilkan prestasi siswa yang rendah. Dari hasil analisis data, telah terbuki bahwa terdapat pengaruh yang signifikan antara partisipasi siswa dengan prestasi belajar melaksanakan komunikasi bisnis. Hal ini sesuai dengan teori dan penelitian yang telah dilakukan sebelumnya yang menyebutkan bahwa semakin tinggi partisipasi siswa akan meningkatkan prestasi belajar.

Berdasarkan hasil pengujian diperoleh hasil bahwa disiplin belajar dan partisipasi berpengaruh signifikan terhadap prestasi belajar siswa melaksanakan komunikasi bisnis. Hasil penelitian ini terlihat dari $\mathrm{F}$ hitung sebesar 34,540 dengan nilai signifikansi sebesar 0,000 kurang dari 5\% sehingga dapat disimpulkan bahwa disiplin belajar dan partisipasi siswa secara simultan berpengaruh signifikan terhadap prestasi belajar. Besarnya pengaruh disiplin belajar dan partisipasi siswa terhadap prestasi belajar sebesar 76,0\% sedangkan $24,0 \%$ dipengaruhi oleh faktor-faktor lain yang tidak dijelaskan dalam penelitian ini.

Hal ini sesuai dengan pendapat Tu'u (2004) yang menyatakan bahwa pencapaian prestasi belajar yang baik selain karena adanya tingkat kecerdasan yang cukup, baik, dan sangat baik, juga didukung oleh adanya disiplin sekolah 
yang ketat dan konsisten, disiplin individu dalam belajar, dan juga karena perilaku yang baik.

Hal ini juga sesuai dengan penelitian sebelumnya yang digunakan sebagai rujukan oleh peneliti. Penelitian yang dilakukan oleh Sakdiyah (2007) hasil penelitiannya mengemukakan bahwa secara simultan terdapat pengaruh positif antara disiplin belajar dan partisipasi siswa terhadap prestasi belajar. Hasil yang ditemukan dilapangan menunjukkan bahwa dengan adanya disiplin belajar yang tinggi dan partisipasi siswa yang tinggi, maka akan semakin tinggi pula prestasi belajar siswa.

Berdasarkan hasil penelitian menunjukkan bahwa percaya diri tidak bisa menjadi variabel moderasi bagi disiplin belajar dan prestasi belajar siswa. Variabel moderating1 yang merupakan selisih mutlak dari variabel Zdisiplin belajar dan Zpercaya diri tidak ditemukan hubungan yang signifikan. Dengan kata lain dalam penelitian ini percaya diri bukan merupakan variabel moderasi antara disiplin belajar dan prestasi belajar.

Lauster (2002) menyatakan bahwa orang yang terlalu percaya diri ada kalanya sering bertindak tidak hati-hati dan bertingkah laku seenaknya. Seseorang yang bertindak dengan kepercayaan pada diri sendiri yang berlebihan, sering memberikan efek negatif. Kepercayan diri memiliki banyak karakteristik sifat yang dapat berubah sewaktu-waktu tergantung mood (mobile feel) atau tidak selalu bersifat positif. Percaya diri tidak berpengaruh sebagai moderasi pengaruh disiplin belajar terhadap prestasi belajar melaksanakan komunikasi bisnis siswa kelas X di Kecamatan Dawarblandong. Dari hasil temuan diketahui bahwa sikap disiplin belajar yang dimiliki oleh setiap siswa tidak selalu didukung dengan memiliki kepercayaan tinggi. Namun sebaliknya siswa yang memiliki disiplin rendah memiliki kepercayaaan yang tinggi.

Berdasarkan hasil analisis menunjukkan bahwa percaya diri berpengaruh sebagai variabel moderasi bagi partisipasi dan prestasi belajar siswa. Variabel moderating2 yang merupakan selisih mutlak dari variabel Zpartisipasi dan Zpercaya diri ditemukan hubungan yang positif dan signifikan. Dengan kata lain dalam penelitian ini percaya diri merupakan variabel moderasi antara partisipasi dan prestasi belajar siswa.

Hasil penelitian ini mendukung penelitian Rocca (2010), yang menyebutkan bahwa percaya diri siswa dapat memberikan pengaruh yang positif terhadap partisipasi yang kemudian akan meningkatkan prestasi belajar.

Percaya diri berpengaruh sebagai moderasi pengaruh partisipasi terhadap prestasi belajar melaksanakan komunikasi bisnis siswa kelas X di Kecamatan Dawarblandong. Dari hasil temuan diketahui bahwa partisipasi yang tinggi dengan percaya diri tinggi akan berpengaruh terhadap peningkatan prestasi belajar. Pelajaran komunikasi bisnis membutuhkan interaksi dan aktifitas yang baik dikelas. Dengan adanya partisipasi dan percaya diri yang baik akan memberikan kemudahan dalam kegiatan belajar mengajar melaksanakan komunikasi bisnis dikelas. Dalam hal ini rata-rata partisipasi dan percaya diri siswa SMK di Kecamatan Dawarblandong tergolong tinggi, sehingga berdampak positif terhadap peningkatan prestasi belajar melaksanakan komunikasi bisnis siswa.

Berdasarkan hasil pengujian diperoleh hasil bahwa disiplin belajar, partisipasi, dan percaya diri sebagai moderasi berpengaruh signifikan terhadap 
prestasi belajar siswa melaksanakan komunikasi bisnis. Hasil penelitian ini terlihat dari Fhitung sebesar 97,512 dengan nilai signifikansi sebesar 0,000 kurang dari 5\% sehingga dapat disimpulkan bahwa disiplin belajar dan partisipasi siswa secara simultan berpengaruh signifikan terhadap prestasi belajar. Besarnya pengaruh disiplin belajar, partisipasi siswa, dan percaya diri sebagai moderasi terhadap prestasi belajar sebesar $84,7 \%$ sedangkan $15,3 \%$ dipengaruhi oleh faktorfaktor lain yang tidak dijelaskan dalam penelitian ini. Penelitian ini mendukung penelitian yang dilakukan Rocca (2010). bahwa percaya diri berpengaruh positif terhadap partisipasi siswa dan selanjutnya akan meningkatkan prestasi belajar.

Prestasi belajar melaksanakan komunikasi bisnis siswa kelas X SMK di Kecamatan Dawarblandong tergolong tinggi. Dimana beberapa factor yang mempengarusi prestasi belajar tersebut adalah disiplin belajar, partisipasi, dan percaya diri siswa. Hal tersebut tidak lepas juga dari pengaruh guru dalam mengajar, yang selalu mencoba untuk mengajak siswa agar selalu disiplin dalam belajar, aktif, dan mencoba untuk meningkatkan percaya diri mereka. Mengingat mata pelajaran melaksanakan komunikasi bisnis adalah pelajaran yang sangat dibutuhkan saat ini dalam dunia kerja, adanya stimulant yang baik dari guru dan pihak sekolah terhadap ketiga variabel tersebut diharapkan mampu memberikan motivasi terhadap siswa untuk terus mengembangkan diri. Tidak hanya dalam prestasi belajar akademiknya tetapi juga dalam disiplin belajar, partisipasi aktif di kelas, dan kepercayaan dirinya.

\section{SIMPULAN}

Berdasarkan pembahasan dan hasil analisis data yang dilakukan dalam penelitian ini dapat disimpulkan sebgai berikut: Ada pengaruh signifikan disiplin belajar siswa terhadap prestasi belajar komunikasi bisnis siswa kelas X SMK di Kecamatan Dawarblandong. Hal ini menunjukkan bahwa semakin tinggi disiplin belajar siswa maka akan berpengaruh terhadap semakin tingginya prestasi belajar siswa; Ada pengaruh signifikan partisipasi siswa terhadap prestasi belajar komunikasi bisnis siswa kelas X SMK di Kecamatan Dawarblandong. Hal ini menunjukkan bahwa semakin tinggi partisipasi siswa maka akan berpengaruh terhadap semakin tingginya prestasi belajar siswa; Ada pengaruh signifikan disiplin belajar dan partisipasi siswa terhadap prestasi belajar komunikasi bisnis siswa kelas X SMK di Kecamatan Dawarblandong. Hal ini menunjukkan bahwa semakin tinggi disiplin belajar dan partisipasi siswa maka akan berpengaruh terhadap semakin tingginya prestasi belajar siswa; Tidak terdapat pengaruh percaya diri siswa sebagai variabel moderasi pengaruh disiplin belajar siswa terhadap prestasi belajar komunikasi bisnis siswa kelas X SMK di Kecamatan Dawarblandong. Hal ini dapat dikatakan bahwa percaya diri tidak dapat menjadi moderasi bagi disiplin belajar dan prestasi belajar siswa; Terdapat pengaruh signifikan percaya diri siswa sebagai variabel moderasi pengaruh partisipasi siswa terhadap prestasi belajar komunikasi bisnis siswa kelas X SMK di Kecamatan Dawarblandong. Hal ini dapat dikatakan bahwa percaya diri dapat menjadi moderasi bagi partisipasi dan prestasi belajar siswa; Terdapat pengaruh signifikan percaya diri siswa sebagai variabel moderasi pengaruh disiplin belajar dan partisipasi siswa terhadap prestasi belajar komunikasi bisnis siswa kelas X SMK di Kecamatan Dawarblandong. Hal ini dapat dikatakan bahwa percaya diri dapat 
menjadi moderasi bagi disiplin belajar dan partisipasi siswa terhadap prestasi belajar siswa.

Berdasarkan simpulan hasil penelitian tersebut di atas, maka ada beberapa saran yang perlu penulis sampaikan sebagai berikut : Disiplin belajar siswa perlu ditingkatkan untuk meningkatkan prestasi belajarnya. Skor yang paling rendah pada variabel disiplin belajar terdapat pada indikator persiapan belajar, untuk itu disarankan siswa lebih disiplin dalam persiapan belajar sebelum menerima pelajaran dikelas. Sehingga nantinya siswa akan lebih siap dan maksimal dalam menerima pelajaran yang disampaikan oleh guru; Siswa diharapkan selalu berpartisipasi aktif dalam proses pembelajaran. Partisipasi siswa dalam pelaksanaan pembelajaran adalah sangat penting, karena dari sinilah guru dapat memberikan perhatian yang berbeda kepada mereka yang kurang berpartisipasi. Partisipasi siswa dalam belajar dapat ditunjukkan dengan keaktifannya dalam proses belajar mengajar, perhatian saat guru menerangkan di kelas, dan menanyakan apa yang menjadi ganjalan dalam pikirannya serta dapat berkomunikasi timbal balik dalam pembelajaran. Guru juga diharapkan untuk bisa memberikan kegiatan pembelajaran yang dapat mengaktifkan siswa seoptimal mungkin, sehingga siswa tersebut mampu mengubah tingkah lakunya menjadi lebih baik dan siswa betul-betul berperan dan berpartisipasi aktif dalam melakukan kegiatan belajar; Percaya diri merupakan salah satu faktor yang sangat penting dalam komunikasi, sehingga percaya diri tinggi perlu dimiliki untuk meningkatkan prestasi dan kemampuan komunikasi siswa. Untuk mengatasi rasa percaya diri yang rendah, diperlukan dukungan emosional dan persetujuan sosial dari orang lain merupakan pengaruh yang penting bagi rasa percaya diri remaja. Disini peranan guru sangat penting untuk memberikan dukungan, melatih dan meningkatkan percaya diri pada siswa; Dari hasil penelitian ini masih ada beberapa faktor lain yang mempengaruhi prestasi belajar, untuk itu perlu diadakan suatu penelitian lanjutan dengan variabel lain untuk mengetahui faktor-faktor lain yang berpengaruh terhadap prestasi belajar.

\section{DAFTAR RUJUKAN}

Cheek, G Jimmy, 2005. Relationship of Supervised Agricultural Experience Program Participation and Student Achievement. Journal of Agricultural Education. Vol. 35, No. 2, PP. 76-83

Darsono M., 2002. Belajar dan Pembelajaran. Semarang: IKIP Semarang Press.Depdikbud

Goleman, Daniel, 2003. Emitional Intelligence (terjemahan). Jakata : PT Gramedia Pustaka Utama.

Hurlock, Elizabeth, 2000. Psikologi perkembangan (suatu pendekatan sepanjang rentang kehidupan). Jakarta: PT Gelora Aksara Prata

Lauster, Peter, 2002. Tes Kepribadian (Alih Bahasa: D.H Gulo). Edisi Bahasa Indonesia. Cetakan Ketigabelas. Jakarta: Bumi Aksara.

Mulyasa, E., 2003. Kurikulum Berbasis Kompetensi. Konsep; Karakteristik dan Implementasi. Bandung : P.T. Remaja Rosdakarya.

Nurmalina, K. \& Syaifullah, 2010. Memahami Pendidikan Kewarganegaraan Bandung: UPI Lab Pendidikan Kewarganegaraan. 
Pasternak, Rachel, 2013. Discipline, Learning Skills And Academic Achievement. Journal of Art and Education, vol. 1 (1) pp. 1-11, June 2013

Rocca, Kelly A., 2010. Student participation in the college classroom: An Extended Multidisciplinay Literature Review. Communication Education. Vol. 59, No. 2, April 2010, pp. 185-213

Sakdiyah, Eva M., 2007. Pengaruh Motivasi, Disiplin, Dan Partisipasi Siswa Dalam Pembelajaran Terhadap Prestasi Belajar. Jurnal Pendidikan ekonomi. Vol 2 No.2. 2007, pp. 165-184

Saputro, Singgih T., 2012. Pengaruh Disiplin Belajar Dan Lingkungan Teman Sebaya Terhadap Prestasi Belajar Mahasiswa. Jurnal Pendidikan Akuntansi Indonesia. Vol. X No.1. 2012, pp. 78-97

Suryabrata, Sumadi, 2005. Psikologi Pendidikan. Jakarta: Raja Grafindo Persada.

Tu'u, Tulus, 2004. Peran Disiplin pada Perilaku dan Prestasi Siswa. Jakarta : PT Gramedia Widiasarana Indonesia 